\title{
Pulmonary Acute Lesions After Caustic Exposure
}

\author{
A.-S. Advenier ${ }^{1}$, G. Lorin de la Grandmaison ${ }^{2 *}$
}

'Department of Forensic Medicine, Claude Bernard Lyon 1 University, Hospices Civils de Lyon, France.

${ }^{2}$ Department of Forensic Medicine and Pathology, Versailles-Saint-Quentin University, AP-HP, Raymond Poincaré Hospital, Garches, France.

\section{Article Info}

\section{Article Notes}

Received: January 24, 2018

Accepted: April 11, 2018

\section{*Correspondence:}

Dr. Geoffroy Lorin de la Grandmaison, Department of

Forensic Medicine and Pathology, Raymond Poincaré Hospital,

104 Boulevard Raymond Poincaré, 92380 Garches, France; Telephone: +33147 107681 ;

Fax: +3314710 76 83;

Email: g.lorin@aphp.fr

( 2018 Lorin de la Grandmaison G. This article is distributed under the terms of the Creative Commons Attribution 4.0 International License.

\section{Keywords}

Caustic

Chemical pulmonary burns

Respiratory damage

Pneumonitis

Dyspnea

Oedema

\section{ABSTRACT}

Although lesions related to chemical burns concern digestive tract first, pulmonary damage can also be observed, in cases of inhalation or secondary to gastric aspiration. Pulmonary lesions after caustic exposure are non-specific. Multiple factors may influence the pattern of lesions, including the nature of the caustic substance, the duration of contact, the amount of the substance encountering the tissue and the length of postingestion survival. Significant complications of caustic ingestion such as chemical pneumonitis can develop in the first days or later. This article summarizes the most frequent pulmonary lesions according to the corrosive agent (gas, solid and liquid caustic, arsenic).

\section{Introduction}

Caustic ingestion and inhalation continues to be a significant problem world-wide especially in developing countries and particularly in children under 6 years. Ingestion and skin contact are the most commonly encountered means of exposure in chemical burn cases ${ }^{1}$. Accidental ingestion occurs most often in infants and toddlers, but it is less common in adults in whom chemical ingestion is often deemed to be suicidal behaviour ${ }^{2}$. Digestive corrosive burns, generally reaching the upper digestive tract, can be categorized by depth, from superficial erosion to full-thickness necrosis ${ }^{3,4,5}$. Acids cause severe lesions of the stomach, mainly in the pyloric region, leading to strictures, but generally spare the esophagus ${ }^{6,7}$. Microscopic lesions after acid exposure show that mucosa is first concerned, with extensive local venous thrombosis, interstitial edema, haemorrhage and inflammatory infiltrate, possible perforation when the whole wall is affected by coagulative necrosis ${ }^{8}$. Alkalis deeply penetrate into tissues, typically, esophagus is the prime target of alkali injury ${ }^{2}$. If great quantities of caustic substance are drunk, the duodenum may be involved ${ }^{9}$. Microscopic lesions may have a similar aspect as those found after acid ingestion. Complications of caustic exposure can involve chemical pneumonia, secondary to inhalation or to aspiration.

The presented short review aims at examining main pulmonary lesions after caustic exposure in both lethal and non-lethal cases.

\section{Review}

The aggressiveness of a caustic agent depends on several factors ${ }^{10-13}$, especially the nature and concentration of the product, duration of contact, amount of the substance that touches the 
skin, respiratory tract or gastrointestinal tract, length of exposure, regional epidermal or mucosal properties, penetrability of the chemical, physicochemical properties and speed of action.

Lesions related to chemical burns have been studied through case reports, clinical analyses and autopsy series. They generally concern digestive tract and more rarely lungs.

Severe caustic ingestion can cause critical tracheobronchic burns characterized by necrotic lesions. Those lesions constitute a severe complication, leading in somes cases to death. In case of an ulcerating or pre-splitting aspect appearing in localised necrotic lesions, the treatment can consist in a tracheobronchic plasty in emergency ${ }^{14}$.

Contrary to digestive damage, there is no specific pulmonary lesion between acid and bases described in literature.

Gases and toxic industrial or household fumes attack the lung ${ }^{15}$. At sufficient dosage these agressive agents have first of all a "suffocating" action as well as a caustic and corrosive action. Pulmonary oedema is the main lesion, due to a direct action on the bronchial epithelium and an indirect action by disturbance of surfactant metabolism. It is mainly an interstitial oedema, which can be secondarily endo-alveolar. Differential diagnosis is not always easy to achieve. The possibility of burns of the respiratory pathways (blast) must be considered. These elements can moreover be associated with lesions due to toxic inhalation. In case of survival, fibrosis can later develop.

After heavy ammonia (a weak base) poisoning, an irritating and caustic gas, the intensity of the lesions and the mortal risk are proportional to the quantity of gas per $\mathrm{m}^{3}$ of air $^{16}$. The most recent lesions, which appear during the first three days, consist of a sharp lung oedema sometimes associated with a pulmonary emphysema. Later on, the main lesion is a pneumopathy (pulmonary infection, bronchiectasis, pulmonary fibrosis).

Acute inhalation toxicity of lithium combustion aerosols was studied in rats ${ }^{17,18}$. Respiratory difficulty, perioral and perinasal encrustation were observed. The most prominent lesions are necrotizing laryngitis and ulcerative rhinitis. Pulmonary lesions represented a secondary extension of the upper respiratory tract lesions rather than a primary manifestation of lithium toxicity ${ }^{17}$. These lesions are often accompanied by areas of squamous metaplasia, and, in some cases, a suppurative bronchopneumonia or aspiration pneumonia, probably secondary to the laryngeal lesions ${ }^{18}$.

In 2006, Mattos and al. ${ }^{19}$ observed the effects of solid corrosive soda after ingestion. If esophagus was the first internal organ concerned, damage to the pulmonary parenchyma and trachea due to this base occurred at $33.66 \%$ concentration after 10 minutes, whereas $1.83 \%$ concentration was sufficient for esophagal epithelial necrosis. According to this study, higher amount of caustic is necessary to damage pulmonary tract, as compared with the digestive tract.

Hydrogen peroxide, an acid molecule, which is found in numerous products, in particular household products ${ }^{20}$, causes toxicity via three main mechanisms: corrosive damage, oxygen gas formation and lipid peroxidation. Ingestion of hydrogen peroxide may cause irritation of the gastrointestinal tract with nausea, vomiting, haematemesis and foaming at the mouth; the foam may obstruct the respiratory tract or result in pulmonary aspiration. Although most inhalational exposures cause little more than coughing and transient dyspnea, inhalation of highly concentrated solutions of hydrogen peroxide can cause severe irritation and inflammation of mucous membranes, with coughing and dyspnea. Shock, coma and convulsions may ensue and pulmonary oedema may occur up to 24-72 hours post exposure.

Paraquat (trivial name, corresponding to $\mathrm{N}, \mathrm{N}^{\prime}$-dimethyl$4,4^{\prime}$-bipyridinium dichloride (systematic name), is an organic compound with the chemical formula [(C6H7N)2] $\mathrm{Cl} 2$ ) used as herbicid. Heavy exposure to paraquat usually results in death, either due to gastrointestinal caustic lesions, shock, and acute respiratory distress syndrome or related to the progressive development of pulmonary fibrosis associated with refractory hypoxemia ${ }^{21}$. If early administration of an antioxidant therapy, including deferoxamine and acetylcysteine may be useful, associated with measures that prevent digestive absorption or enhance elimination to limit systemic toxicity in potentially fatal paraquat poisoning, respiratory damage can be irreversible. The main prognostic factors appear to be the route of administration. Inhalation of paraquat aerosols and/or contamination of skin with the herbicide seems to have better outcome than ingestion, in particular according to the amount of poison. Above $50 \mathrm{mg} / \mathrm{kg}$, patients die of circulatory failure within $72 \mathrm{~h}$; between 35 and $50 \mathrm{mg} / \mathrm{kg}$, a progressive pulmonary fibrosis occur ${ }^{22}$.

Exposure to arsenic, notably through drinking waterfrom in arsenic-affected areas of Bangladesh and India, has been described in Asian population ${ }^{23,} 24$. The mechanism remains unclear; however, earlier human and animal studies indicate deposition and permanent structural changes in the lung epithelium as a result of arsenic exposure ${ }^{25}$. Animal studies showed tissue inflammation and increased morphologic changes in the lung with increasing arsenic exposure ${ }^{26,27 .}$

Main characteristics of these corrosive agents are summarized in table 1. 
Table 1 : Respiratory tract and lung lesions according to the nature of the agent.

\begin{tabular}{|c|c|c|c|c|c|c|c|}
\hline Agent & Gases & Lithium combustion & Paraquat & Arsenic & $\begin{array}{c}\text { Hydrogen peroxide } \\
\text { (acid) }\end{array}$ & $\begin{array}{c}\text { Ammonia } \\
\text { (base) }\end{array}$ & $\begin{array}{l}\text { Solid caustic soda } \\
\text { (base) }\end{array}$ \\
\hline $\begin{array}{l}\text { Main } \\
\text { lesions }\end{array}$ & $\begin{array}{l}\text { Interstitial and } \\
\text { endo-alveolar } \\
\text { edema } \\
\text { +/- epithelial } \\
\text { burns }\end{array}$ & $\begin{array}{l}\text { Necrotizing laryngitis, } \\
\text { ulcerative rhinitis, } \\
\text { secondary pulmonary } \\
\text { lesions (squamous } \\
\text { metaplasia, suppurative } \\
\text { bronchopneumonia, } \\
\text { aspiration pneumonia) }\end{array}$ & $\begin{array}{l}\text { Pulmonary } \\
\text { irritation. } \\
\text { Later : } \\
\text { pulmonary } \\
\text { fibrosis }\end{array}$ & $\begin{array}{l}\text { Inflammation, } \\
\text { increased } \\
\text { morphologic } \\
\text { changes in lung } \\
\text { tissue }\end{array}$ & $\begin{array}{l}\text { Severe irritation } \\
\text { and inflammation } \\
\text { of mucous mem- } \\
\text { branes, } \\
\text { pulmonary edema }\end{array}$ & $\begin{array}{l}\text { First days : pul- } \\
\text { monary oedema } \\
\text { +/- pulmonary } \\
\text { emphysema } \\
\text { Later : pneu- } \\
\text { mopathy }\end{array}$ & $\begin{array}{l}\text { Epithelial necrosis of } \\
\text { the trachea and the } \\
\text { lung at high concen- } \\
\text { tration. }\end{array}$ \\
\hline
\end{tabular}

\section{References}

In our previous study ${ }^{28}$, we showed that many organic and nonorganic agents can cause chemical pneumonitis. The presented microscopic findings, although generally unspecific $^{29,30,31}$, often showed intra-alveolar edema, activated macrophages, congestion and pulmonary inflammation. Hyaline membranes and capillary haemorrhages can also be found in this regard, as observed after lye ingestion. These are not specific to the type of agent and can be caused by a large variety of potential toxic insults $^{32}$, such as infections, high concentrations of oxygen, toxic inhalants, drug toxicity, radiation and many other ingestants including kerosene, denatured rapeseed oil and paraquat. Moreover, the tracheo-bronchial tree was the site of mild burns, with lesions similar to those seen on the skin. We suppose that respiratory burns can result either from gastric acidity or from the direct chemical effects of the caustic agent. The severity of chemical-induced respiratory damage depends on the nature and amount of the inhalated agent ${ }^{33}$.

We also pointed out that pulmonary lesions may have developed during the aspiration of the agent from the stomach. Alternatively, patients may not have ingested enough agent and/or the agent, particularly alkalis, may not have been aggressive enough to cause respiratory lesions.

\section{Conclusions}

Pulmonary damage after caustic exposure are rare, except in cases of gas or vapor exposition or as a result of gastric aspiration. They frequently consist in epithelial necrosis, intra-alveolar edema, activated macrophages, congestion and pulmonary inflammation. With time, fibrosis can be a serious complication, leading to chronic respiratory disease.

\section{Funding}

This research received no specific grant from any funding agency in the public, commercial, or not-for-profit sectors.

\section{Conflict of Interest}

The authors declare that they have no conflict of interest.
1. Bronstein C, Spyker DA, Cantilena JrLR, et al. 2010 Annual Report of the American Association of Poison Control Centers' National Poison Data System (NPDS): 28th Annual Report. Clin Toxicol. 2011 ; 49 (10) : 910-941.

2. Pavelites JJ, Kemp WL, Barnard JJ, et al. Deaths related to chemical burns. Am J Forensic Med Pathol. 2011; 32 (4): 387-392.

3. Ertekin C, Alimoglu O, Akyildiz $\mathrm{H}$, et al. The results of caustic ingestions. Hepatogastroenterology. 2004; 1397-400.

4. Ashraf S, Al-Malki AS, Ashraf I, et al. Corrosive gastritis: an extreme outcome. BMJ Case Rep. 2009; bcr02.2009.1612.

5. Gimmon Z, Durst AL. Acid corrosive gastritis. A plea for delayed surgical approach. Am J Surg. 1981; 381-3.

6. Ananthakrishnan N, Parthasarathy G, Kate V. Acute corrosive injuries of the stomach: a single unit experience of thirty years. ISRN Gastroenterol. 2011; Epub 2010 Oct 28.

7. Gillis DA, Higgins G, Kennedy R. Gastric damage from ingested acid in children. J Pediatr Surg. 1985; 494-6.

8. Cabanne F, Bonenfant JL. Inflammation in F Cabanne JL Bonenfant. Anatomie pathologique: Principes de pathologie générale et spéciale, Les Presses de l’Université Laval, Québec, Maloine S.A. Editeur, Paris ; 1980 : pp. $115-151$.

9. Moore WR. Caustic ingestions. Pathophysiology, diagnosis, and treatment. Clin Pediatr (Phila). 1986; 192-6.

10. Matshes EW, Taylor KA, Rao VJ. Sulfuric acid injury. Am J Forensic Med Pathol. 2008; 29 (4): 340-345.

11. Waasdorp Hurtado CE, Kramer RE. Salicylic acid ingestion leading to esophageal stricture. Pediatr Emerg Care. 2010; 26 (2): 146-148.

12. Ramasamy K, Gumaste VV. Corrosive ingestion in adults. J Clin Gastroenterol. 2003; 37 (2): 119-124.

13. Postlethwait RW. Chemical burns of the esophagus. Surg Clin North Am. 1983; 63 (4): 915-924.

14. Deneuville M, Andreassian B, Charbonnier JY, et al. Severe tracheobronchial complications of the ingestion of caustics in adults. A case of perforation healed with a pulmonary patch. J Chir (Paris). 1984 Jan; 121(1): 1-6.

15. Huguenard P, Richard A, Desfemmes C. Pulmonary edema due to inhalation of gas and vapors. Ann Anesthesiol Fr. 1975; 16 Spec No 2-3:95-9.

16. Woto-Gaye G, Mendez V, Boye IA, et al. Death from ammonia poisoning: anatomo-pathologic features. Dakar Med. 1999; 44(2): 199-201.

17. Rebar AH, Greenspan BJ, Allen MD. Acute inhalation toxicopathology of lithium combustion aerosols in rats. Fundam Appl Toxicol. 1986 Jul; 7(1): 58-67.

18. Greenspan BJ, Allen MD, Rebar AH. Inhalation toxicity of lithium combustion aerosols in rats. J Toxicol Environ Health. 1986; 18(4): 627-37. 
19. Mattos GM, Lopes DD, Mamede RC, et al. Effects of time of contact and concentration of caustic agent on generation of injuries. Laryngoscope. 2006 Mar; 116(3): 456-60.

20. Watt BE, Proudfoot AT, Vale JA. Hydrogen peroxide poisoning. Toxicol Rev. 2004; 23(1): 51-7.

21. Lheureux P, Leduc D, Vanbinst R, et al. Survival in a case of massive paraquat ingestion. Chest. 1995 Jan; 107(1): 285-9.

22. Bismuth C, Garnier R, Dally S, et al. Prognosis and treatment of paraquat poisoning: a review of 28 cases. J Toxicol Clin Toxicol. 1982 Jul; 19(5): 461-74.

23. Parvez F, Chen Y, Yunus M, et al. Arsenic exposure and impaired lung function. Findings from a large population-based prospective cohort study. Am J Respir Crit Care Med. 2013 Oct 1; 188(7): 813-9. doi: 10.1164/rccm.201212-22820C.

24. von Ehrenstein OS, Mazumder DN, Yuan Y, et al. Decrements in lung function related to arsenic in drinking water in West Bengal, India. Am J Epidemiol. 2005 Sep 15; 162(6): 533-41. Epub 2005 Aug 10.

25. Rosenberg HG. Systemic arterial disease and chronic arsenicism in infants. Arch Pathol. 1974; 97: 360-365.

26. Lantz RC, Chau B, Sarihan P, et al. In utero and postnatal exposure to arsenic alters pulmonary structure and function. Toxicol Appl Pharmacol. 2009; 235: 105-113.
27. Nemery B. Metal toxicity and the respiratory tract. Eur Respir J. 1990; 3: 202-219.

28. Advenier AS, Dorandeu A, Charlier P, et al. Microscopic acute lesions after caustic exposure. Forensic Sci Int. 2014 Jan; 234: 57-63. doi: 10.1016/j.forsciint.2013.10.039. Epub 2013 Nov 12.

29. White RS, Templeton PA. Chemical pneumonitis. Radiol Clin North Am. 1992; 30 (6): 1231-1243.

30. Dettmeyer RB. Aspiration and inhalation, in: Dettmeyer R.B. (Ed.), Forensic Histopathology Fundamentals and Perspectives, SpringerVerlag, Berlin. 2011; pp. 211-229.

31. Larsen ST, Verder H, Nielsen GD. Airway effects of inhaled quaternary ammonium compounds in mice. Basic Clin Pharmacol Toxicol. 2012; 110(6): 537-543.

32. Katzenstein AL, Acute lung injury patterns: diffuse alveolar damage and bronchiolitis obliterans-organizing pneumonia, in: Katzenstein A.L. (Ed.), Katzenstein and Askin's Surgical pathology of nonneoplastic lung disease. Major problems in pathology, fourth edition, Saunders Elsevier. 2006; pp. 17-49.

33. Andujar P. Nemery B. Acute and subacute chemical pneumonitis. Rev Mal Respir. 2009; 26(8): 867-885. 